\title{
A DOAÇÃO DE MATERIAL GENÉTICO ENTRE IRMÃS SOB UMA PERSPECTIVA LIBERAL
}

\author{
Jadir Rafael da Silva Filho* \\ Rita de Cássia Resquetti Tarifa Espolador**
}

\section{RESUMO:}

Discorre-se sobre o anonimato do doador e do receptor de material genético na reprodução assistida e sua afronta à autonomia e garantias individuais. Busca-se abordar o procedimento de reprodução humana assistida, especificidades e precauções, bem como o seu atual tratamento no ordenamento jurídico brasileiro. Expõe-se o anonimato como exigência pelo Conselho Federal de Medicina para a realização do procedimento de reprodução assistida e suas implicações jurídicas e bioéticas. Além disso, apreende-se a proposta pelo respeito ao exercício da autonomia do doador baseado nos princípios libertários presentes na Constituição Federal, e garantia do receptor ao direito de reprodução e planejamento familiar.

Palavras-chave: Reprodução Humana assistida. Anonimato. Autonomia. Bioética. Liberdade.

\section{THE DONATION OF GENETIC MATERIAL BETWEEN SISTERS UNDER A LIBERAL PERSPECTIVE}

\begin{abstract}
:
The anonymity of the donor and the recipient of genetic material in assisted reproduction is discussed and its affront to the autonomy and individual guarantees. It seeks to address the procedure of assisted human reproduction, specificities and precautions, as well as its current treatment in the Brazilian legal system. Anonymity is exposed as a requirement by the Federal Medical Council for the performance of the assisted reproduction procedure and its legal and bioethical implications. In addition, the proposal for respect for the exercise of the donor's autonomy based on the libertarian principles of the Federal Constitution, and the recipient's guarantee of the right of reproduction and family planning, is apprehended.
\end{abstract}

Key-words: Assisted Human Reproduction. Anonymity. Autonomy. Bioethics. Freedom.

\section{INTRODUÇÃO}

Com os avanços das biotecnologias e o aumento do diagnóstico de infertilidade masculina e feminina no mundo, os procedimentos de reprodução assistida como inseminação

\footnotetext{
* Mestrando do Programa de Mestrado em Direito Negocial da Universidade Estadual de Londrina. Bolsista vinculado à CAPES/Fundação Araucária de Apoio ao Desenvolvimento Científico e Tecnológico do Paraná. Email: jadir_rafael@hotmail.com

** Doutora em Direito pela Universidade Federal do Paraná, Professora da Universidade Estadual de Londrina e Coordenadora do projeto de pesquisa "Biodireito nos Contratos". E-mail: rita.tarifa@gmail.com
} 
artificial e fertilização in vitro foram aprimorados e passaram a ser cada vez mais contratados e utilizados.

O presente artigo tem como objetivo levar o leitor à reflexão acerca da autonomia privada nos negócios jurídicos de reprodução assistida e o amparo constitucional, possuindo como objetivo último a análise da Resolução nº 2.168/2017 do Conselho Federal de Medicina, sob uma perspectiva liberal.

Parte do fato de que as técnicas de reprodução assistida são um dos principais negócios biojurídicos realizados atualmente no Brasil, bem como que o desejo de constituir uma família encontra amparo no artigo 226, §7º da Constituição Federal.

Nesse intento, por meio de uma abordagem dialética, busca-se questionar a validade da proibição pelo Conselho Federal de Medicina da identificação dos doadores e receptores de material genético nos procedimentos de reprodução assistida, apresentando como problemática a hipótese de doação entre irmãos.

No primeiro item, apresenta-se os procedimentos de reprodução humana assistida e um breve apanhado histórico. No item seguinte expõe-se a exigência do anonimato dos doadores de materiais genéticos, sua previsão no código de ética médica e seus fundamentos. Em seguida, analisa-se a exigência do anonimato no plano da bioética. Por fim, demonstra-se a incompatibilidade da exigência de anonimato com o exercício da autonomia privada e as liberdades individuais.

As resoluções do Conselho Federal de Medicina e os provimentos do Conselho Nacional de Justiça seguem avançando nas regulamentações acerca dos procedimentos de reprodução assistida e seus respectivos desdobramentos jurídicos, fazendo-se necessário o destaque de alguns de seus dispositivos.

Com isso, é possível apontar questionamentos acerca da interferência do Estado na vida de seus cidadãos, a afronta às liberdades individuais e a autonomia da vontade, o conflito de interesses entre os sujeitos envolvidos na espécie de negócio biojurídico apontado, bem como a ausência de legislação sobre o tema e o amparo constitucional para a solução de eventuais problemas.

\section{REPRODUÇÃO HUMANA ASSISTIDA}


Para tratar da reprodução humana assistida, mostra-se importante antes diferenciar a sexualidade e a reprodução, as quais estivem por longo período de tempo interligadas, como explica Giana Lisa Zanardo Sartori:

A Sexualidade e a Reprodução estiveram unidas ao longo da história humana, mas com a crescente intervenção da medicina, no século XX, desenvolvendo técnicas reprodutivas (pera facilitar a contracepção e também a concepção), esse fato se alterou significativamente, embora seja difícil imaginar tal situação. Tanto uma categoria quanto à outra são partes integrantes das relações humanas (SARTORI, 2015, 129).

O ser humano conhecia como única maneira de procriar a relação sexual entre homem e mulher. A procriação sem o ato de relação sexual era narrada como ao místico e divino, como bem pontua Regina Fiuza Sauwen e Severo Hryniewicz, ao apresentarem casos na mitologia de mulheres que engravidaram sem a realização do ato sexual:

Estes mitos mostram que desde tempos remotos o homem pensou na possibilidade de fecundação fora do ato sexual. Em clichê psicanalítico, poder-se-ia até falar de uma interferência do superego, na medida em que há um contraste entre a pureza da procriação e a impureza e animalidade antiestética do ato sexual (SAUWEN; HRYNIEWICZ, 2000, p. 89).

Exemplo que melhor ilustra a pureza da procriação desvinculada do ato sexual pode ser extraído da religião cristã, considerando que Jesus Cristo nasceu de uma mulher virgem e se tornou o filho de Deus, demonstrando a concepção de pureza e importância da procriação.

A procriação, para muitos, é necessária para o gozo de uma vida feliz, ou seja, o indivíduo tem como um de seus objetivos a geração de descendentes e a constituição de uma família. Trata-se de valor intrínseco em nossa sociedade que possui assento constitucional, conforme previsão do artigo 226, $\$ 7^{\circ}$, da Constituição Federal. O texto constitucional assegurou expressamente a liberdade para que o casal exerça o seu planejamento familiar, bem como garantiu que o Estado disponibilizaria todo recurso científico para o exercício deste direito.

\footnotetext{
${ }^{1}$ Art. 226. A família, base da sociedade, tem especial proteção do Estado.

[...]

$\S 7^{\circ}$ Fundado nos princípios da dignidade da pessoa humana e da paternidade responsável, o planejamento familiar é livre decisão do casal, competindo ao Estado propiciar recursos educacionais e científicos para o exercício desse direito, vedada qualquer forma coercitiva por parte de instituições oficiais ou privadas.
} 
Ocorre que alguns indivíduos possuem dificuldade em gerar um filho, seja em decorrência de patologias hereditárias, seja como efeito colateral de tratamentos médicos agressivos e debilitantes, como é o caso da quimioterapia. Assim "a infertilidade é a ausência de gravidez após, no mínimo, um ano de relações sexuais regulares e sem a utilização de métodos contraceptivos" (BAZZACO et al., 2014, p. 135).

A infertilidade é considerada problema de saúde conforme Classificação Estatística Internacional de Doenças e Problemas Relacionados com a Saúde (International Statistical Classification of Diseases and Related Health Problems), na qual a infertilidade masculina recebe o código N46 e a infertilidade feminina os códigos N970, N971, N972, N973, N974, N978 e N979². Consequentemente, aplica-se procedimentos médicos e psicológicos para a sua superação.

Com os avanços da tecnologia, do conhecimento médico e científico, tornou-se possível a reprodução assistida de seres humanos, por meio de procedimentos seguros tanto para aqueles pacientes que buscam ser pais, como para a criança que será gerada. Foi "a partir de 1978, com o nascimento de Louise Brown, produto de uma experiência bem-sucedida de fertilização in vitro (FIV), novas tecnologias para a reprodução assistida (RA) foram desenvolvidas" (BAZZACO et al., 2014, p. 135).

Atualmente, mostra-se cada vez mais acessível a reprodução assistida, tratando-se de um procedimento que inclusive é disponibilizado pelo Sistema Único de Saúde do Brasil na Lei n ${ }^{\circ}$ 9.263/96, que regulou o artigo 226, §7º da Constituição Federal.

A reprodução humana assistida consiste em técnicas que facilitam o processo de procriação, dentre elas podem ser citadas: a "relação programada" consistente na pratica de relação sexual após indução da ovulação por medicamento; a "inseminação artificial" intrauterina na qual o sêmen é introduzido com auxílio de instrumentos diretamente no organismo da mulher; a "fertilização in vitro" em que a fusão entre espermatozoides e óvulos ocorre fora do corpo da mulher para, posteriormente a formação do embrião, ser transferido para o organismo feminino (ALVES; OLIVEIRA, 2014, p. 68).

\footnotetext{
${ }^{2}$ Os códigos correspondem as seguintes classificações:

N970 - Infertilidade feminina associada à anovulação;

N971 - Infertilidade feminina de origem tubária;

N972 - Infertilidade feminina de origem uterina;

N973 - Infertilidade feminina de origem cervical;

N974 - Infertilidade feminina associada à fatores do parceiro;

N978 - Infertilidade feminina de outra origem;

N979 - Infertilidade feminina não especificada.
} 
Em que pese a "relação programada" compor o quadro de técnicas de reprodução assistida, a presente pesquisa não dedicará atenção a este procedimento, uma vez que não há a possibilidade de receber material genético de terceiros, tendo o presente trabalho recorte especifico quanto a doação de material genético destinado aos procedimentos de reprodução humana assistida ${ }^{3}$.

Observa-se que a sociedade foi se adequando aos avanços científicos e biotecnológicos que resultaram na possibilidade de reprodução sem sexualidade e realizada em laboratório, de modo que "a Reprodução Assistida (RA), enquanto intervenção sobre o 'processo natural' da procriação, gera questionamentos sobre os benefícios e perigos - tanto físicos quanto psicológicos - da artificialidade inserida na vida do homem a partir do processo biotecnológico" (SAUWEN; HRYNIEWICZ, 2000, p. 89-90).

Considerando que as técnicas de reprodução assistida buscam auxiliar a resolução das dificuldades de reprodução humana, bem como que são procedimentos realizados por médicos habilitados, o Conselho Federal de Medicina estabelece as normas éticas aplicadas as referidas técnicas, sendo o órgão responsável por supervisionar a ética profissional em toda a República nos termos do artigo $2^{\circ 4}$ da Lei $n^{\circ} 3.268 / 57$.

Ocorre que ao disciplinar as referidas normas éticas, em observância a Lei $n^{\circ}$ 11.105/05 - Lei de Biossegurança, o Conselho Federal de Medicina, considerando como fatores motivadores o excessivo número de mulheres com baixa probabilidade de gravidez devido à idade, que necessitam a recepção de óvulos doados, editou a Resolução $n^{\circ}$ $2.013 / 2013^{5}$, estabelecendo que "os doadores não devem conhecer a identidade dos receptores e vice-versa".

Em decorrência da ausência de legislação específica sobre o tema, a referida norma ética editada pelo Conselho Federal da Medicina é o parâmetro normativo seguido pelos profissionais da medicina nos procedimentos de reprodução assistida, ocasionando conflito

\footnotetext{
${ }^{3}$ Também não é objeto do presente trabalho abordar todos as teorias e técnicas de reprodução humana assistida existentes.

${ }^{4}$ Art . $2^{\circ} \mathrm{O}$ conselho Federal e os Conselhos Regionais de Medicina são os órgãos supervisores da ética profissional em toda a República e ao mesmo tempo, julgadores e disciplinadores da classe médica, cabendo-lhes zelar e trabalhar por todos os meios ao seu alcance, pelo perfeito desempenho ético da medicina e pelo prestígio e bom conceito da profissão e dos que a exerçam legalmente.

${ }^{5}$ A Resolução $n^{\circ} 2.013 / 2013$, foi revogada pela Resolução $n^{\circ} 2.121 / 2015$, que posteriormente foi revogada pela resolução $n^{\circ}$ 2168/2017. Entretanto, em nenhum dos dispositivos houve alteração do texto indicado, qual seja: “Os doadores não devem conhecer a identidade dos receptores e vice-versa".
} 
com direitos e garantias provenientes do ordenamento jurídico brasileiro, conforme será abordado no tópico seguinte.

\title{
3 O ANONIMATO DO DOADOR DE MATERIAL GENÉTICO
}

Conforme anteriormente mencionado, com os avanços médicos e científicos os procedimentos de reprodução assistida popularizaram-se, permitindo àqueles que são inférteis a geração de um filho.

Em muitos dos procedimentos médicos para a realização das mencionadas técnicas de reprodução, os materiais genéticos utilizados para a inseminação artificial (RA) ou fertilização in vitro (FIV), advém de doação:

\begin{abstract}
A doação de óvulos, assim como a de sêmen, é perfeitamente admitida pela legislação brasileira; da leitura do texto constitucional é possível depreender a admissibilidade da respectiva transferência, desde que gratuita. E em ambas as situações (doação de óvulo e de sêmen), em razão de não haver lei formal sobre o assunto, costuma-se preservar o anonimato do (a) doador (a) (MEIRELLES, 2004, p. 44).
\end{abstract}

A Lei $n^{\circ} 11.105 / 05$ - Lei de Biossegurança é omissa quanto a doação de material genético, dispondo apenas que sua comercialização configura o crime previsto na lei que dispõe sobre a remoção de órgãos e tecidos - Lei $\mathrm{n}^{\circ}$ 9.434/97, mais especificamente o seu artigo $15^{6}$, com reclusão de três a oito anos e multa.

Por sua vez, a mencionada Lei $n^{\circ} 9.434 / 97 \mathrm{em}$ seu artigo $1^{\circ}$, parágrafo único ${ }^{7}$, estabelece que não são compreendidos como tecidos para os fins de transplante e tratamento o sangue, o esperma e o óvulo.

Assim, atualmente apenas o Conselho Federal de Medicina estabelece normas, ainda que de cunho ético-profissional, sobre as técnicas de reprodução humana assistida, conforme é possível extrair da Resolução CFM nº 2.168/2017.

\footnotetext{
${ }^{6}$ Art. 15. Comprar ou vender tecidos, órgãos ou partes do corpo humano:

Pena - reclusão, de três a oito anos, e multa, de 200 a 360 dias-multa.

Parágrafo único. Incorre na mesma pena quem promove, intermedeia, facilita ou aufere qualquer vantagem com a transação.

${ }^{7}$ Art. $1^{\circ}$ A disposição gratuita de tecidos, órgãos e partes do corpo humano, em vida ou post mortem, para fins de transplante e tratamento, é permitida na forma desta Lei.

Parágrafo único. Para os efeitos desta Lei, não estão compreendidos entre os tecidos a que se refere este artigo o sangue, o esperma e o óvulo.
} 
Há no Brasil bancos de armazenamento e clinicas especializadas na criopreservação de espermatozoides, óvulos, embriões, entre outras espécies de material genético, como por exemplo sangue do cordão umbilical.

Com o objetivo de assegurar o direito ao anonimato do doador, para a garantia de inexistência de vínculo familiar e a isenção de qualquer dever ou direito em relação a criança gerada por meio do material genético doado, restou estabelecido pelo Conselho Federal de Medicina que "os doadores não devem conhecer a identidade dos receptores e vice-versa".

Trata-se de disposição que possui fundamento ético nos riscos de questionamento da filiação biológica da futura criança, que pode desencadear um desequilíbrio emocional de todos os envolvidos, desestabilizando as relações familiares.

Ainda que não seja objeto do presente trabalho, mostra-se importante destacar que a garantia do anonimato ao doador de esperma ou óvulo, entra em conflito direito com o direito ao reconhecimento da origem genética da futura criança gerada.

Há ainda outra implicação decorrente da determinação do Conselho Federal de Medicina de que doadores de material genético não devem ser identificados, uma vez que esta impede a doação de material genético entre irmão ou parentes, constituindo clara restrição ao direito de dispor do próprio corpo, ou seja, trata-se de hipótese em que há reflexos e interferências diretamente nos direitos individuais do doador e do receptor.

É possível que o Conselho Federal de Medicina, autarquia dotada de personalidade jurídica de direito público, por meio de resolução, possa estabelecer dispositivo deontológico a ser seguido pelos profissionais médicos, mas que interfira na liberdade de disposição do próprio corpo pelo ser humano, ferindo assim a sua liberdade individual? Trata-se de questionamento que ilustra as transformações sociais ocorridas diante das novas biotecnologias e que serão abordadas em uma perspectiva bioética no próximo tópico seguinte.

\section{UM OLHAR BIOÉTICO SOBRE O ANONIMATO DO DOADOR}

Após a segunda grande guerra mundial, que contabilizou 60 (sessenta) milhões de pessoas mortas e 40 (quarenta) milhões de refugiados (COMPARATO, 2015, p. 225), dois grandes documentos foram elaborados e inauguraram o processo de emancipação do ser humano como sujeitos de direito, o Código de Nuremberg de 1947 e a Declaração Universal 
de Direitos do Homem de 1948, o primeiro proveniente do julgamento de criminosos de guerra e o segundo como instrumento de proteção a direitos do homem nos regimes democráticos de direitos.

Ainda que no decorrer do Processo de Nuremberg refletiu-se sobre a proteção humana submetida a pesquisas científicas para a criação de barreiras éticas, mostra-se inadequada a afirmação de que o pensamento bioético nasce neste período:

Em primeiro lugar, porque a Nuremberg não se colocou o problema do abuso da ciência cometido por um regime totalitário. Portanto, já o ponto de partida da posição é errado e desnorteante. Em segundo lugar, porque não é verdadeiro que a medicina norte-americana fosse muito mais avançada do que a de outros países ocidentais, nem que naquele país se sentisse a exigência de uma "barreira ética" para a ciência. (MORI, 2006, p. 23)

Em 1964, com a publicação da Declaração de Helsinki pela Associação Médica Mundial (Word Medical Association - WMA), é adotado o primeiro instrumento que trata da ética destinado a pesquisa clinicas com seres humanos, definindo como princípio básico que “A pesquisa clínica deve se acomodar à moral e princípio científicos que justificam a pesquisa médica e deve se basear em experimentos animais e laboratoriais ou outros fatos

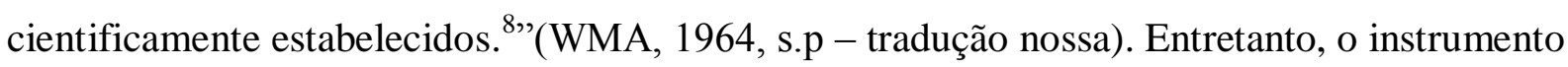
também não pode ser considerado como nascedouro da bioética, considerando que seu principal objetivo é a disciplina da ética profissional e não um pensamento interdisciplinar.

O neologismo ${ }^{9}$ do termo bioética é atribuído a Van Rensselaer Potter, que em 1971 utilizou o termo na obra "bioethics: bridge to the future", definindo-o como "ciência da sobrevivência humana" (POTTER, 2016, p. 26).

Para Van Rensselaer Potter a forma de "equilibrar os apetites culturais contra as necessidades fisiológicas em termos de políticas públicas" (POTTER, 2016, p. 51), seria por meio de um estudo interdisciplinar capaz de "chegar a conceitos válidos de ordem em termos de moralidade, tradição, costumes e leis" (POTTER, 2016, p. 87), com objetivo de beneficiar da condição de vida humana e sua relação com a natureza.

\footnotetext{
${ }^{8}$ Clinical research must conform to the moral and scientific principles that justify medical research and should be based on laboratory and animal experiments or other scientifically established facts.

${ }^{9}$ O termo já utilizado pelo pastor protestante alemão Paul Max Fritz Jahr em 1927, no trabalho publicado na revista Kosmos.
} 
O termo bioética passa a ganhar um novo significado com a criação pelo governo dos Estados Unidos da América da National Commission for the Protection of Human Subjects of Biomedical and Behavioral Research (Comissão Nacional para a Proteção dos Seres Humanos em Pesquisa Biomédica e Comportamental), órgão responsável pela publicação em 1979 do documento denominado Belmont Report, no qual estabeleceu os princípios éticos aplicados em pesquisa com humanos e denominados de "respeito às pessoas, beneficência e justiça" ${ }^{10}$ (USA, 1979, s.p - tradução nossa).

A bioética então passa a ser sistematizada nos princípios mencionados, os quais passaram a ser conhecidos mundialmente como princípio da Autonomia, Beneficência, NãoMaleficência e Justiça. A diferença em relação ao Belmont Report tem influência da publicação da obra The principles of bioethics, publicada em 1979 por Tom L. Beauchamp e James F. Childress (BEAUCHAMP; CHILDRESS, 2013, p. 137).

A evolução do significado da palavra bioética demonstra que a análise terminológica possui reflexos práticos importantes, os quais permitiram que atualmente o termo pudesse ser definido como o "estudo interdisciplinar, ligado à ética, que investiga, na área das ciências da vida e da saúde, a totalidade das condições necessárias a uma administração responsável da vida humana em geral e da pessoa humana em particular" (SAUWEN; HRYNIEWICZ, 2000, p. 21).

Dentre os princípios bioéticos, o da autonomia é aquele que mais reflete a filosofia liberal que caracteriza a sociedade norte americana:

O princípio da autonomia, denominado no Relatório Belmont princípio do respeito às pessoas, requer que os indivíduos com capacidade de deliberar sobre suas escolhas pessoais devam ser tratados com respeito pela sua capacidade de decisão; as pessoas têm o direito de decidir sobre as questões relacionadas ao seu corpo e à sua vida, e quaisquer atos médicos devem ser autorizados pelo paciente (ROBERTI, 2007, p. 64).

O princípio bioético da autonomia tende a prevalecer em eventual conflito com os demais, considerando que há situações clinicas e médicas em que, por compaixão, o mais digno ao ser humano é o respeito de sua última vontade.

\footnotetext{
${ }^{10}$ The principles of respect of persons, beneficence and justice.
} 
Além do respeito à autonomia do paciente, necessário verificar também se os procedimentos médicos cumprem com o princípio da beneficência/não-maleficência:

\begin{abstract}
O princípio da beneficência requer o atendimento por parte do médico ou do geneticista aos mais importantes interesses das pessoas envolvidas nas práticas biomédicas ou médicas, para atingir seu bem-estar, evitando, na medida do possível, quaisquer danos. Baseia-se na tradição hipocrática de que o profissional da saúde, em particular o médico, só pode usar o tratamento para o bem do enfermo, segundo sua capacidade e juízo, e nunca para fazer o mal ou praticar a injustiça (DINIZ, 2006, p.17).
\end{abstract}

Trata-se de princípio que reflete a essência das ciências médicas, ou seja, do cuidado ao ser humano. Sua importância é essencial para a minimização de danos. Como afirmado, em casos de conflito entre os princípios bioéticos, a conduta médica apenas será benéfica se respeitar a autonomia do paciente.

Por fim, "o princípio da justiça, também chamado princípio da equidade, traz como norte a imparcialidade que deve haver quando da distribuição dos riscos e benefícios alcançados com as pesquisas científicas em seres humanos" (ROBERTI, 2007, p.67). Trata-se de um princípio voltado a privilegiar a pesquisa cientifica para a manutenção do progresso e obtenção de novas técnicas, em um exercício de balanceamento entre risco e benefício.

Sob o prisma dos princípios bioéticos, não há fundamentos explícitos para a defesa do anonimato na doação de óvulos e espermatozoides. A exigência do anonimato busca evitar os riscos de desestabilização das relações familiares, valor que por meio de um exercício hermenêutico possa encontrar amparo nos princípios da beneficência e justiça, mas que em eventual conflito com a autonomia tende a ser superado.

Busca-se, portanto, proteger o doador dos ônus do vínculo familiar e o equilíbrio emocional da criança e todos os envolvidos. Entretanto, quando todos estiverem cientes dos ônus e bônus inerentes ao processo de doação e recepção dos materiais, não há fundamento bioético que proíba a flexibilização do anonimato.

Inexistindo impedimentos bioéticos na identificação do doador de espermatozoide ou óvulo, mostra-se necessária uma análise baseada em fundamentos e valores constitucionais, como será feito no tópico seguinte. 


\section{A PREVALENÇA DA AUTONOMIA PRIVAdA NA DOAÇÃO DE MATERIAL GENÉTICO}

Como anteriormente demonstrado, o anonimato do doador de esperma e óvulos mostra-se exigência constante nas normas de ética médica, amparada em fundamento destinado à proteção de ambos os envolvidos no procedimento, quais sejam, o doador e o receptor. O primeiro é protegido quanto a possibilidade de imputação de paternidade ou maternidade de alguém que assim não desejava, ferindo, portanto, a liberdade e intimidade do indivíduo. Por sua vez, o segundo é protegido quanto a negação de paternidade ou maternidade da criança gerada, ferindo assim o planejamento familiar.

Entretanto, a jurisprudência do Tribunal de Regional Federal da $3^{\text {a }}$ Região, flexibiliza a aplicação da resolução do Concelho Federal de Medicina em caso específico de doação de material genético entre irmãs:

CONSTITUCIONAL E PROCESSUAL CIVIL. REPRODUÇÃO ASSISTIDA - FERTILIZAÇÃO IN VITRO - ILEGITIMIDADE ATIVA E PASSIVA AD CAUSAM - INOCORRÊNCIA - DOADORA E RECEPTORA DE ÓVULOS - DOAÇÃO ENTRE IRMÃS - REGRA DO ANONIMATO - RESOLUÇÃ̈OCFM N $\mathrm{N}^{\circ} 2121 / 2015$ INAPLICABILIDADE - PLANEJAMENTO FAMILIAR - SAÚDE DIREITO FUNDAMENTAL. [...] 4. A adoção dos procedimentos e técnicas de reprodução assistida encontra guarida nos direitos constitucionais ao planejamento familiar (art. 226, § $7^{\circ}, \mathrm{CF} / 88$ ) e à saúde (art. 196, CF/88), bem como no princípio da autonomia privada. 5. Em harmonia com a Constituição, o Código Civil reconhece, no artigo $\S 2^{\circ}$ do art. 1.565, a importância do planejamento familiar, direito cujo exercício deve contar com apoio educacional e financeiro do Estado. 6. Nesse cenário de tutela da aspiração reprodutiva como consequência do direito fundamental à saúde e ao planejamento familiar e, consequentemente, de autorização e facilitação de acesso às técnicas de procriação medicamente assistida, eventuais restrições, para se legitimarem, devem encontrar suporte lógico, científico e jurídico. 7. O direito à reprodução por técnicas de fecundação artificial não possui, por óbvio, caráter absoluto. Contudo, eventuais medidas restritivas de acesso às técnicas de reprodução assistida, ínsito ao exercício de direitos fundamentais de alta envergadura, consoante demonstrado, só se justificam diante do risco de dano efetivo a um bem relevante, análise a ser perpetrada, não raro, em face do caso concreto (BRASIL, 2015, s.p.) 
A decisão judicial colacionada privilegia o direito individual da mulher receptora do material genético de ser mãe, bem como a autonomia da vontade da doadora de dispor de seu material genético em favor de sua irmã, ou seja, reconhece que a determinação do Conselho Federal de Medicina afronta os direitos individuais.

Ainda que não haja uma legislação específica sobre os procedimentos de reprodução assistida, nem mesmo sobre a doação de material genético entre irmãs conforme anteriormente demonstrado, a discussão no caso narrado desdobra-se na busca de identificar até que ponto o estado pode interferir na liberdade individual dos seus indivíduos, seja pela criação de leis ou atuação de suas autarquias.

A busca pela proteção das liberdades individuais é uma característica dos indivíduos que compõem a sociedade atual, conforme bem explica Benjamin Constant ao diferenciar os objetivos dos antigos e dos modernos, afirmando que a independência individual é a primeira das necessidades modernas:

\begin{abstract}
Somos modernos que queremos desfrutar, cada qual, de nossos direitos; desenvolver nossas faculdades como bem entendermos, sem prejudicar a ninguém; vigiar o desenvolvimento dessas faculdades nas crianças que a natureza confia à nossa afeição, tão esclarecida quanto forte, não necessitando da autoridade a não ser para obter dela os meios gerais de instrução que pode reunir; como os viajantes aceitam dela os longos caminhos, sem serem dirigidos na estrada que desejam seguir (CONSTANT, 1985, p. 20-21).
\end{abstract}

Trata-se de uma posição liberal, na qual "o dever básico do Estado é impedir a invasão dos direitos produzida pela ingerência indevida dos cidadãos e, sobretudo, dele mesmo" (RAMOS, 2007, p. 309).

Evidente que a referida independência individual não é total e ilimitada, como bem explica Cesar Augusto Ramos:

Para o liberalismo os indivíduos serão livres se forem deixadas para si a escolha das suas decisões, definidas e decididas num campo não arbitrário de interferência, razão pela qual a liberdade passa a ser a chamada de negativa: a ausência de ações que podem criar impedimentos arbitrários e indevidos à livre atividade dos sujeitos (RAMOS, 2005 p. 235). 
Em consonância à característica da liberdade negativa, o texto constitucional prevê no caput de seu artigo $5^{\circ}$ o direito fundamental à liberdade, bem como assegura em seu inciso II que "ninguém será obrigado a fazer ou deixar de fazer alguma coisa senão em virtude de lei”. Contudo, mostra-se importante mencionar que a mencionada previsão não é suficiente para classificar a Constituição brasileira como liberal, uma vez que ela possui previsões ora liberais ora republicanas.

De todo modo, a garantia de não sofrer a interferência arbitrária, nas palavras de Cesar Augusto Ramos:

São liberdades que, definidas por direitos e deveres constitucionais, formam um conjunto articulado de meios e possibilidades legalmente protegidos que permitem aos cidadãos o direito de agir como desejam e impedem interferências indevidas dos outros ou do Estado (RAMOS, 2007, p. 308).

Sobre os princípios libertários, Michael Sandel aponta uma problemática interessante principalmente sobre os direitos à privacidade, à liberdade sexual e de reprodução, afirmando que tais conceitos possuem implicações difíceis de serem superadas, pois "se sou dono do meu corpo, da minha vida e da minha pessoa, devo ser livre para fazer o que quiser com eles (desde que não prejudique os outros) (SANDEL, 2012, p. 90).

As principais implicações de permitir a doação de material genético entre irmãs, podem ser identificadas nas searas da filiação e poder familiar. Isso porque, o conhecimento do doador ou do receptor pode gerar expectativas de direitos e deveres a outra parte. Entretanto, ao se candidatar como doador, independente do fato de ser o material genético destinado a irmão ou não, implícito está a aceitação de que não haverá nenhuma expectativa de direitos e deveres.

No caso fático apresentado para fomentar a problemática do presente trabalho, ao aceitar doar seu material genético à irmã, a doadora exerceu sua autonomia privada que "em termos restritos, corresponde ao espaço de liberdade jurígena, isto é, à área reservada na qual as pessoas podem desenvolver as atividades jurídicas que entenderem" (CORDEIRO, 2005, P. 391). 
Com os avanços da tecnologia a máxima mater semper certa est já não pode mais ser absoluta, considerando que no caso de gestação por substituição, à mulher que gestou e pariu a criança não é atribuída a maternidade:

Necessário, portanto, eleger-se um critério único para determinar a maternidade obtida via gestação de substituição, seja reafirmando o velho brocardo mater semper certa est ("a mãe é sempre certa, posto que determinada pelo parto), seja contrariando-o e estabelecendo os direitos e deveres de mãe a partir de outros elementos, como a vontade da "mãe social" em ter o filho, ou o dado genético herdado pela criança da titular do gameta feminino (óvulo) fecundante (MEIRELLES, 2004, p. 38).

Na hipótese aqui mencionada, a receptora do material genético também é a mãe intencional, podendo ainda se ancorar no brocardo mater semper certa est para a reinvindicação da maternidade, como bem pontuado por Jussara Maria Leal de Meirelles:

Em face da ausência de disposições específicas sobre o assunto, ainda que uma mulher mantenha gestação de óvulo de outra, a mãe jurídica será determinada pelo parto, seguindo-se o sistema tradicionalmente estabelecido. Ausente de previsão legislativa, a hipótese poderá ser levada aos tribunais e buscar-se solução mediante exame genético (DNA), mediante o qual se identificará a "mãe genética" e essa identificação possivelmente atribuirá a esta a maternidade jurídica (MEIRELLES, 2004, p. 45).

Diante da manifestação de autonomia da doadora e da receptora, no conflito entre os interesses da mãe intencional e da mãe biológica em exercer o poder familiar, deve ser levado em consideração que ao exercer o ato de doar o material genético o doador estava ciente da total isenção de direitos e deveres.

Nesse sentido, foi que a Conselho Nacional de Justiça considerando a possibilidade de que o parentesco resulte de outra origem que não seja a biológica, editou o provimento $\mathrm{n}^{\circ}$ 63 , de 14 de novembro de 2017 , que no seu artigo 17 , parágrafo $3^{\mathrm{o}^{11}}$, ao tratar do registro de crianças geradas por meio das técnicas de reprodução assistida, disciplinou que "O conhecimento da ascendência biológica não importará no reconhecimento do vínculo de parentesco e dos respectivos efeitos jurídicos entre o doador ou a doadora e o filho gerado por meio da reprodução assistida".

\footnotetext{
${ }^{11} \S 3^{\circ} \mathrm{O}$ conhecimento da ascendência biológica não importará no reconhecimento do vínculo de parentesco e dos respectivos efeitos jurídicos entre o doador ou a doadora e o filho gerado por meio da reprodução assistida.
} 
Diante da discussão apresentada, importante sopesar as consequências de uma eventual intromissão do Estado na relação privada, como bem abordado por Cesar Augusto Ramos:

Qualquer interferência estatal em favor desta ou daquela concepção particular afeta a autonomia dos sujeitos e o valor da imparcialidade do poder público. Trata-se de garantir os direitos do cidadão, sobretudo a sua liberdade de elaborar e buscar uma determinada concepção racional do bem que, junto com a pluralidade de concepções divergentes, formam a diversidade dos modos de vida das pessoas (RAMOS, 2005, p. 237).

Especificamente quanto a doação de material genético entre irmãs, as partes possuem plena consciência do ato que estão realizando e escolheram realizar tal procedimento, de modo que exercem plenamente sua liberdade e autonomia na tomada de decisões.

Mostra-se necessário refletir sobre os efeitos práticos da exigência de anonimato, considerando que o ordenamento vem evoluindo, ao menos nas normas que cuidam do registro de pessoas civis, para assegurar que a ascendência biológica não resulta em vinculo jurídico e obrigacional decorrente do parentesco. Trata-se de disposição que assegura ao doador qualquer responsabilidade proveniente do vínculo biológico.

Por sua vez, o doador que após ser eficazmente informado e esclarecido sobre o procedimento de doação, livremente realizar a doação de seu material genético destinada a determinado receptor, não pode pleitear o direito ao exercício do poder familiar, considerando que a ascendência biológica não gera vinculo de parentesco, ficando assim asseguro ao receptor o gozo e exercício de seu direito de constituir família e exercer seu planejamento familiar.

Em eventual conflito de interesses entre as partes, deverá sempre considerar o exercício da autonomia privada daqueles que firmaram o negócio biojurídico e a aceitação quanto aos termos referentes a filiação e exercício do poder familiar, bem como o melhor interesse para a criança ou adolescente envolvido.

Assim, observa-se que a exigência feita pelo Conselho Federal de Medicina de que o doador deve necessariamente ser anônimo, encontra resistência dos princípios libertários provenientes da Constituição Federal, devendo ser relativizado em casos como o apresentado, pela ausência de fundamentos bioéticos e jurídicos. 


\section{CONCLUSÃO}

O tema desenvolve-se a partir da proibição pelo Conselho Federal de Medicina de que os doadores de esperma ou óvulo conheçam os receptores e vice-versa, explicitando a evidente relação entre o direito e as novas biotecnologias sob a ótica dos princípios bioéticos consagrados mundialmente.

Aqueles indivíduos que necessitam de material genético doado para exercerem o seu direito constitucionalmente garantido de procriação e planejamento familiar, atualmente devem se socorrer de bancos de armazenamento onde espermatozoides e óvulos ficam criopreservados, não sendo possível solicitar a doação de parentes ou amigos.

Nesse sentido, a proibição do Conselho Federal de Medicina fere a liberdade individual em uma perspectiva liberal. Do mesmo modo, não encontra amparo constitucional, uma vez que a Constituição Federal de 1988 privilegia a liberdade e a autonomia privada do indivíduo na tomada de decisões particulares, não sendo o cidadão obrigado a fazer ou deixar de fazer exceto em virtude da lei, como preceitua o seu artigo $5^{\circ}$, inciso II.

Com a evolução das técnicas de reprodução assistida, principalmente a inseminação artificial e a fertilização in vitro, tornou-se possível a procriação com a geração de laços familiares sem a necessidade de laços biológicos. A evolução social acompanhou esse processo e tornou seguro ao doador, disponibilizar seu material genético sem que com isso ficassem estabelecidos direitos e deveres em face da criança proveniente do material genético.

Ao aceitar realizar a doação de seu material genético, o doador abdica de qualquer direito sobre eventual criança gerada, da mesma forma que deve ter garantida a ausência de qualquer responsabilidade inerente provinda daquela doação. Observa-se que referidas garantias devem ocorrer independentemente de o receptor conhecer ou não a identidade do doador.

As resoluções do Conselho Federal de Medicina devem acompanhar a evolução social decorrente das biotecnologias, para que naqueles casos em que o doador e receptor de material genético se conheçam, ainda assim possa ser possível a realização do procedimento, pois como reconhecido pelo Conselho Nacional de Justiça o vínculo familiar não se forma pela ascendência biológica. 
Por fim, constatou-se que não há no Brasil, legislação específica da reprodução assistida. Contudo, amparado nas normas constitucionais, principalmente no artigo $226, \S 7^{\circ}$, da Constituição Federal, é possível concluir que a proibição de doação de material genético por doador conhecido, principalmente entre irmãos, atenta contra as liberdades individuais do doador e receptor, caracterizando uma afronta aos princípios libertários que foram contemplados pela Carta Magna.

\section{REFERÊNCIAS BIBLIOGRÁFICAS}

ALVES, Sandrina Maria Araújo Lopes Alves; OLIVEIRA, Clara Costa. Reprodução medicamente assistida: questões bioéticas. Revista Bioética. vol. 22, n 1 - 2014. Brasília/DF, Brasil, Conselho Federal de Medicina, 2014, p. 66-75.

BAZZACO, Amanda Albertoni; VALELONGO, Pamela Olivieri; MIZIARA, Ivan Dieb; BARBOSA, Caio Parente. Entendimento do consentimento livre esclarecido na reprodução assistida. Revista Bioética. vol. 22, n 1 - 2014. Brasília/DF, Brasil, Conselho Federal de Medicina, 2014, p. 134-144.

BEAUCHAMP, Tom L.; CHILDRESS, James F. Princípios de ética biomédica. $3^{\circ}$ ed. São Paulo: Edições Loyola, 2013.

BRASIL. Constituição da República Federativa do Brasil de 1988. Diário Oficial da União n. 191-A, de 5 de Out de 1988.

. Tribunal Regional Federal da $3^{\mathrm{a}}$ Região. Apelação Cível no 0007052-

98.2013.4.03.6102/SP. Relator: Desembargador Federal Mairan Maia. Diário da Justiça eletrônico, 23 nov. 2015. Disponível em:

http://web.trf3.jus.br/acordaos/Acordao/BuscarDocumentoGedpro/4733675. Acesso em: 07 jul. 2017.

Lei n. 11.105, de 24 de Março de 2005. Regulamenta os incisos II, IV e V do parágrafo primeiro do art. 225 da Constituição Federal, estabelece normas de segurança e mecanismos de fiscalização de atividades que envolvam organismos geneticamente modificados - OGM e seus derivados, cria o Conselho Nacional de Biossegurança - CNBS, reestrutura a Comissão técnica nacional de Biossegurança - CTNBio, dispõe sobre a Política Nacional de Biossegurança- PNB, revoga a Lei n. 8.974, de 5 de janeiro de 1995, e a Medida Provisória n. 2.191-9, de 23 de Agosto de 2001, e os arts 5, 6 $, 7^{\circ}, 8^{\circ}, 9^{\circ}, 10$ e 16 da Lei n. 10.814, de 15 de dezembro de 2003, e dá outras providências. Diário Oficial da União, Brasília, D.F., 24 de mar. de 2005.

COMPARATO, Fábio Konder. A afirmação histórica dos direitos humanos. 10 ed. São Paulo: Saraiva, 2015. 
CONSELHO FEDERAL DE MEDICINA. Resolução CFM n. 2.121. Adotar as normas éticas para a utilização das técnicas de reprodução assistida-sempre em defesa do aperfeiçoamento das práticas e da observância aos princípios éticos e bioéticos que ajudarão a trazer maior segurança e eficácia a tratamentos e procedimentos médicos- tornando-se o dispositivo deontológico a ser seguido pelos médicos brasileiros e revogando a Resolução CFM n ${ }^{\circ}$ 2.013/13, publicada no D.O.U de 9 de maio de 2013, seção I, p. 119. Diário Oficial da União, Brasília, D.F., de 24 de setembro de 2015, seção I, p.117.

CONSTANT, Benjamin. Da liberdade dos antigos comparada à dos modernos. In.: MONTEIRO, João Paulo e ou. Filosofia Política 2. Porto Alegre: L\&PM Editores (UNICAMP/UFRGS - com apoio do CNPQ), 1985.

CORDEIRO, Antonio Menezes. Tratado de Direito Civil Português, I, Parte Geral, Tomo I, $3^{\mathrm{a}}$ ed. Coimbra: Livraria Almedina, 2005.

DINIZ, Maria Helena. O estado atual do biodireito. 3 ed. aum. e atual. conforme o novo Código Civil (Lei n. 10.406/2002) e a Lei n. 11.105/2005. São Paulo: Saraiva, 2006.

MEIRELLES, Jussara Maria Leal de. Reprodução assistida e exame de DNA: implicações jurídicas. Curitiba: Genesis, 2004.

MORI, Maurizio. A bioética: sua natureza e história. Traduzido por Fermin Roland Schramm. In: BRASIL. Ministério da Saúde. Secretaria de Ciência, Tecnologia e Insumos Estratégicos. Departamento de Ciência e Tecnologia. Capacitação para Comitês de Ética em Pesquisa: volume 1. Brasília: Ministério da Saúde, 2006. p. 20-28.

POTTER, Van Rensselaer. Bioética: pontes para o futuro. Tradução de Diego Carlos Zanella. São Paulo: Edições Loyola, 2016.

RAMOS, César Augusto. A concepção republicana de liberdade como não-dominação. Crítica: Revista de Filosofia. Londrina: Universidade Estadual de Londrina. Vol. 12, número 36, p. 301-336, out. 2007.

César Augusto. O liberalismo político e seus críticos. Crítica: Revista de Filosofia. Londrina: Universidade Estadual de Londrina. Vol. 10, número 32, p. 229-264, out. 2005.

ROBERTI, Maura. Biodireito: novos desafios: com análise penal da Lei n ${ }^{\circ} 11.105$, de 24 de março de 2005 e atualizado de acordo com a Emenda Constitucional n ${ }^{\circ} 45$ de 2004. Porto Alegre: Sergio Antonio Fabris Editora, 2007.

SANDEL, Michael J. Justiça - O que é fazer a coisa certa. Tradução de Heloisa Matias e Maria Alice máximo. $8^{a}$ edição. Rio de Janeiro: Civilização Brasileira, 2012.

SARTORI, Giana Lisa Zanardo. Reprodução humana assistida: um direito fundamental? Curitiba: Appris, 2015.

SAUWEN, Regina Fiuza; HRYNIEWICZ, Severo. O direito "in vitro" da bioética ao biodireito. $2^{\mathrm{a}}$ ed. Rio de Janeiro: Editora Lumen Juris, 2000. 
USA. Office For Human Research Protections. U.s. Department Of Health \& Human Services. The Belmont Report. 1979. Disponível em: https://www.hhs.gov/ohrp/regulationsand-policy/belmont-report/read-the-belmont-report/index.html. Acesso em: 01 abr. 2019.

WORLD MEDICAL ASSOCIATION - WMA. Declaration of Helsinki 1964. Disponível em: https://www.wma.net/what-we-do/medical-ethics/declaration-of-helsinki/doh-jun1964/. Acesso em: 02 abr. 2019. 